\title{
Reactions Induced by Platelet Transfusions
}

\author{
Volker Kiefel \\ Abteilung Transfusionsmedizin, Universitätsklinikum Rostock, Germany
}

\section{Key Words}

Platelet transfusion - Transfusion reactions - Bacterial contamination of blood products · Hemolytic transfusion reactions - Febrile nonhemolytic transfusion reactions

\section{Summary}

Platelet transfusions play a central role in therapeutic regimens for patients with hematologic/oncologic diseases who develop severe thrombocytopenia either in the course of their disease or following cytostatic therapy. Like other blood components, platelet transfusions have achieved a high degree of safety as far as transmission of viral diseases is concerned. However, transfusion of platelet concentrates is accompanied by a high frequency of febrile and anaphylactoid reactions. In rare cases, recipients of platelet concentrates are threatened by severe reactions as septic complications due to bacterial contamination of platelet concentrates, transfusionrelated acute lung injury and severe anaphylactic episodes.

\section{Introduction}

Platelet transfusions play an important role in the prevention of bleeding in severely thrombocytopenic patients, and platelet transfusions may be used to stop bleeding due to thrombocytopenia and in patients with severely impaired platelet function. Platelet transfusions are a relatively safe form of therapy as far as transmission of viral diseases is con-

\section{Schlüsselwörter}

Thrombozytentransfusion - Transfusionsreaktion . Bakterielle Kontamination von Blutkomponenten . Hämolytische Transfusionsreaktionen · Febrile nichthämolytische Transfusionsreaktionen

\section{Zusammenfassung}

Thrombozytentransfusionen spielen eine zentrale Rolle z.B. bei der Behandlung von Patienten mit hämatologisch/onkologischen Erkrankungen, bei denen im Rahmen der Grundkrankheit oder als Folge der Therapie das Risiko einer Blutung entstehen kann. Thrombozytentransfusionen haben wie die Transfusion anderer Blutkomponenten ein hohes Maß an Sicherheit in Bezug auf die Übertragung von Virusinfektionen erreicht. Dennoch sind Thrombozytentransfusionen mit häufigen, für den betroffenen Patienten zwar unangenehmen, meist jedoch nicht bedrohlichen Reaktionen (febrile, anaphylaktoide Reaktionen) verbunden. Seltener kommt es zu schweren Reaktionen: Sepsis infolge Transfusion bakteriell kontaminierter Produkte, transfusionsbedingter akuter Lungenschädigung und schwerer anaphylaktischer Reaktionen.

cerned. This, and the fact that platelet concentrates are now easily available in developed countries, is reflected by the observation that platelets are often transfused under a liberal indication. Compared to fresh frozen plasma and red blood cells, platelet transfusions are accompanied by a high rate of reactions.

The transfusion reactions discussed in this review may be the consequence of immune reactions or may result from bacterial

\section{KARGER}

Fax +497614520714

Information@Karger.de

www.karger.com
() 2008 S. Karger GmbH, Freiburg

Accessible online at:

www.karger.com/tmh 
contamination. Like other blood products, platelet concentrates may transmit viruses like hepatitis $\mathrm{C}$ virus, hepatitis $\mathrm{B}$ virus or human immunodeficiency virus (HIV). As these risks do not differ significantly between platelet concentrates and other blood products, they will not be discussed in this manuscript.

\section{Febrile Non-Hemolytic Transfusion Reactions}

Febrile non-hemolytic transfusion reactions (FNHTRs) are common in recipients of platelet concentrates. They can be defined as rise of body temperature by $1{ }^{\circ} \mathrm{C}$ or more within the first $4 \mathrm{~h}$ of transfusion and normalization of the temperature within $48 \mathrm{~h}$, if transfusion of a bacterially contaminated blood product can be excluded and if no signs of hemolysis are found $[1,2]$. Patients with isolated febrile reactions may otherwise be asymptomatic or may experience rigor and chills. As these reactions usually have no serious long-term effects, they are often not reported and documented as transfusion reactions. Their true incidence has therefore been difficult to assess. Decary et al. [3] estimated the incidence for nonhemolytic transfusion reactions by $0.4 \%$ (of products transfused) in patients receiving platelet concentrates; probably, most of these reactions were febrile reactions. Enright et al. [4] reported a rise in temperature in $0.3 \%$ of transfusions, but they found transfusion reactions in $1.6 \%$ of transfusions if chills with rigors were included in the analysis. If febrile reactions were related to patients transfused, these figures were higher (22\%, patients with chills/rigors included). Blumberg et al. [5] found febrile reactions in patients with malignancies after $3.4 \%$ of platelet transfusions. In a study published by Kelley et al. [6], febrile reactions occurred in $4.6 \%$ of pooled platelet products but only in $1.1 \%$ of products that were 3 days old or less. These figures indicate that FNHTRs are quite common. Transfusion experiments by Heddle et al. [7] suggest that reactions may even occur in about $30 \%$. It has been known for a long time that transfusion of blood components may cause febrile reactions due to leukocyte [8] or platelet antibodies in patients who had received previous transfusions. In the patients studied by Decary et al. [3], 64\% of patients with nonhemolytic transfusion reactions had leukocyte antibodies as compared to $30 \%$ of control patients. De Rie et al. [1] further characterized antibodies as human leukocyte antigen (HLA-), platelet- and granulocyte antibodies in patients with febrile reactions. HLA antibodies were the most common, followed by platelet antibodies and the least common granulocyte antibodies. With the introduction of glycoprotein-specific tests, it became possible to more precisely identify serologic specificities in immunized patients. In a series of 252 polytransfused patients with hematologic/oncologic diseases [9], 42\% of patients presented with HLA class I antibodies, 37\% had HLA antibodies without accompanying platelet specific (human platelet antigen, HPA) antibodies, and in 20 patients (7.9\%)
HPA antibodies were found. Specificities of HPA antibodies in this series were, in decreasing order of frequency: HPA-5b, HPA-1b, HPA-5a, HPA-2b, HPA-1a.

Febrile reactions have not been abolished with the introduction of leukocyte depletion of blood components. Therefore, Blumberg et al. [5] studied a platelet-derived substance, soluble CD40 ligand (sCD40L, CD154), in supernatants of platelet concentrates as possible cause of FNHTRs. These authors assume that platelet-associated CD40L and sCD40L induce prostaglandin $\mathrm{E}_{2}$ synthesis (inducing fever) and synthesis of pro-inflammatory cytokines in a variety of cells in the recipient, including endothelial cells and fibroblasts [10,11]. As CD40L is assumed to be released by platelet activation during platelet concentrate preparation, this effect cannot be suppressed by leukocyte depletion. Similarly, Klüter et al. [12] related allergic reactions to enhanced levels of RANTES, a chemokine released by platelets.

In immunized patients, febrile reactions and - more importantly - antibody-mediated refractoriness to platelet transfusions can be avoided by analysis of HLA/HPA antibody specificities and transfusion of apheresis platelets from compatible donors. If febrile reactions are not related to alloantibodies, the question arises if premedication with antipyretic drugs like paracetamol (acetaminophen) might be effective in prevention of FNHTRs. This has been instituted in form of a 'general premedication' policy of use of antipyretic drugs [13] or may be restricted to patients who showed to be prone to febrile reactions during earlier transfusions. Only very few studies have been made to study the usefulness of premedication; mostly acetaminophen was used as an antipyretic drug and diphenhydramin for the prevention of allergic reactions (see below). The small prospective and randomized trial by Wang et al. [14] revealed no difference in incidence of FNHTRs between the group of patients treated with acetaminophen and the control group. Also the retrospective analysis of the pediatric patients yielded no favorable effect [15].

\section{Allergic/Anaphylactic Reactions}

Allergic and anaphylactic reactions occur after platelet transfusions with similar frequency as FNHTRs. The risk of allergic reactions is between 0.09 and $21 \%$ in patients who receive platelet transfusions [16]. Allergic reactions are highly variable in severity. Manifestations may occur as isolated pruritus and urticaria as the only dermal manifestations. Systemic reactions may include bronchoconstriction, hypotensive reactions and shock. Only a minority of allergic reactions is associated with a rise in temperature of $1{ }^{\circ} \mathrm{C}$ or more; the authors of [17] observed this in $5 \%$.

The pathogenesis of allergic reactions is highly heterogeneous. Possible reasons for reactions related to transfusion of platelet concentrates include (i) $\mathrm{IgE}$ and $\mathrm{IgG}$ antibodies in the recipient against plasma proteins in the transfused blood compo- 
Table 1. Transfusion principles for minimizing the risk of hemolytic transfusion reactions induced by anti-A/anti-B in the plasma of platelet concentrates [31], with modifications

- Prefer transfusion of ABO-identical platelets, if possible. However, if HLA class I and HPA antibodies exist, prefer HLA/HPA compatibility over ABO compatibility

- If ABO-identical platelets are not available, try to avoid minor-incompatible platelet transfusions

- Minor-incompatible platelet transfusion cannot be avoided

- Try to avoid group O platelets, prefer group A, B platelets

- Use donors without detectable anti-A/anti-B hemolysin, with low titers of anti-A/anti-B agglutinins

- Try to reduce the amount of plasma in the platelet product (replace by platelet additive solution, plasma from $\mathrm{AB}$ donor)

nent, (ii) transfusion of cytokines, chemokines, and histamine generated in the platelet product during preparation and storage.

The best-known type of anaphylactic reaction is induced by $\operatorname{IgA}$ deficiency of the recipient and subsequent formation of anti-IgA [18]. Patients lacking only one IgA subclass may form subclass-specific anti-IgA; other patients may get immunized against allotypes on the $\operatorname{IgA}$ molecules. Patients with such antibodies of 'limited specificity' usually experience less severe anaphylactic reactions than patients with complete IgA deficiency and class-specific anti-IgA $[18,19]$. The currently used criterion for $\operatorname{IgA}$ deficiency has been defined at serum IgA levels of $0.05 \mathrm{mg} / \mathrm{dl}$ or less [18]. One might expect that diagnosis of transfusion reactions due to anti-IgA is simple. However, the following circumstances indicate the problems related to diagnosis of this condition: IgA-related major transfusion reactions are observed with a rate of 1 in 50,000 transfusions [19]. This rate is much lower than the rate of individuals with IgA deficiency, which is about 1 in 1200 [18] as estimated in healthy blood donors. However, anti-IgA was identified in $21 \%$ of $\operatorname{IgA}$-deficient healthy blood donors using a passive hemagglutination assay [20], and anti-IgA titers of individuals in populations of donors and of IgA-deficient patients with a history of transfusion reactions studied by Sandler et al. [18] overlapped. This means that serological investigation with this technique cannot be used to reliably predict transfusion reactions. Some of the techniques currently in use for the identification of $\operatorname{IgA}$ antibodies detect $\operatorname{IgG}$ (and/or IgM) antibodies against IgA: the passive hemagglutination assay and a recently developed commercial particle-gel centrifugation assay.

In Japanese patients, an equivalent to anti-IgA-induced anaphylactic transfusion reactions has been observed in haptoglobin-deficient patients. Shimada et al. [21] identified haptoglobin deficiency in 367 (1.6\%) of patients with a history of sudden onset of anaphylactic transfusion reactions.

For patients with severe anaphylactic transfusion reactions most probably related to anti-IgA, transfusion of washed red blood cell concentrates has been recommended. If platelet and plasma transfusions are required, products from IgA-deficient donors are recommended, if they are available. In patients with severe initial anaphylactic reactions, transfusions should be performed in an intensive care setting. On the other hand, fatal anti-IgA reactions seem to be rather rare; Sandler in his manuscript published in 2006 quotes a single fatal case [22]. The observation by Ahrens et al. [23] who found that patients with common variable immunodeficiency (CVID) with anti-IgA may develop immune tolerance remains to be confirmed for the clinical setting of sensitized IgA-deficient patients and transfusion of blood components containing plasma [23].

\section{Hemolytic Transfusion Reactions}

Sometimes it is not possible to provide ABO group-identical platelets to a patient. This may especially be the case if patients are broadly sensitized against HLA and platelet-specific alloantibodies and if only one or few ABO-different but HLA/HLA-compatible donors are available. In ABO 'majorincompatible' platelet transfusions (e.g. O recipient receives $\mathrm{A}, \mathrm{B}$ or $\mathrm{AB}$ platelet product), anti-A/anti-B in the recipient may reduce platelet increments [24]. In minor-incompatible transfusions, hemolytic reactions occur [25-28]. Although these reactions are very rare, even fatal hemolytic episodes have been observed [29]. Usually, platelet concentrates from blood group $\mathrm{O}$ donors were implicated in these severe transfusion reactions. Isoagglutinin titers from implicated donors tended to be high, but - due to the heterogeneity of the methods used - no reliable threshold for the exclusion or prediction of severe hemolytic reactions can be given [30]. Recommendations resulting from a recent international survey on ABO-incompatible platelet transfusion [31] for the prevention of immune hemolysis are summarized in table 1 .

\section{Other Immunologically Mediated Reactions Caused by Transfusion of Platelets}

Plasma of (usually female) patients may contain antibodies against antigens on granulocytes, HLA class II and HLA class I antibodies. Such antibodies may induce transfusion-related acute lung injury (TRALI), a dangerous, sometimes fatal transfusion reaction discussed in the manuscript by Bux and Sachs in this issue. Plasma, especially from female donors, may also contain platelet-specific alloantibodies. In patients with normal platelet counts receiving fresh frozen plasma with platelet alloantibodies, transient episodes of immune thrombocytopenia usually referred to as passive alloimmune thrombocytopenia have been observed. As patients receiving platelet concentrates are usually thrombocytopenic, such reactions will probably not be noted as a consequence of platelet 
transfusions. A similar situation exists in the case of posttransfusion purpura (PTP) observed in (mostly) female patients after transfusion of whole blood or red cell concentrates in the past. It can be speculated that such reactions may happen after transfusion of platelets, but probably most of them will be missed in patients who are already markedly thrombocytopenic before platelet transfusion. Contaminating T-lymphocytes in platelet concentrates may also cause transfusionassociated graft-versus-host disease (TA-GvHD) in a similar way as this is observed after transfusion of red cells.

\section{Reactions Following Transfusion of Bacterially Contaminated Platelet Concentrates}

Platelet concentrates have to be stored under continuous agitation at about $22^{\circ} \mathrm{C}$ for up to 5 days. This comparatively high temperature implicates a higher probability (as compared to red cells) of bacterial overgrowth with potential risks for the transfused patient. Under unfavorable conditions, recipients of bacterially contaminated blood components may develop shock with hyperpyrexia. Other frequently encountered symptoms include chills, vomiting, tachycardia and hypotension. Possible sources for contamination are bacteria from the donor's skin and asymptomatic bacteremia at the time of donation. Bacteria may also enter the bags or tubings through defects of the blood bag system. Attempts have been made to prevent transfusion of dangerous platelet concentrates by screening platelet concentrates for bacterial contamination. In the study reported by Fang et al. [32], 0.064\% of 350,068 platelet apheresis concentrates were initially tested positive, with $0.019 \%$ confirmed tests. Platelet transfusions from 38 initially positive products did not induce septic transfusion reactions in a single case. However, even after initiation of screening for bacterial contamination, recipients of three products that initially tested negative showed severe reactions; one pa- tient died. Two more studies with a similar pattern of results were published in the meantime $[33,34]$. In the study by te Boeckhorst et al. [33], initially positive screening results were identified in 203 of 28,104 cases (0.72\%). Recipients of 113 potentially contaminated products did not experience transfusion reactions, whereas two recipients of two products initially tested as negative showed severe reactions [33]. The study reported by Schrezenmeier et al. (German Red Cross) [34] revealed an initial rate of reactivity of $0.54 \% ; 22$ products confirmed as positive were transfused but only two recipients developed fever. Again two recipients of a split platelet concentrate initially tested as negative developed severe reactions due to contamination of the products by Klebsiella pneumoniae.

To conclude, in rare cases, severe septic transfusion reactions still happen after platelet transfusion; they cannot be safely prevented with screening tests (e.g. the BacT/ALERT system) currently in use. Although these screening tests yield positive results in up to $0.5 \%$ of cases, only a minority of these products cause septic reactions.

\section{Conclusion}

Platelet transfusions are highly effective in many clinical settings. On the other hand, the rate of transfusion reactions is rather high: FNHTRs and 'allergic' reactions are observed in frequencies of up to $20-30 \%$. Although the majority of these reactions are not dangerous, they cause discomfort to the patient. Only a subset of febrile reactions is caused by alloantibodies in the recipient. Attempts to suppress febrile and anaphylactic reactions with premedication have not been generally successful. Rare but dangerous transfusion reactions related to platelet concentrates include TRALI, septic complications induced by bacterially contaminated products, and hemolytic transfusion reactions.

\section{References}

$>_{1}$ de Rie MA, van der Plas-van Dalen CM, Engelfriet $\mathrm{CP}$, von dem Borne AE: The serology of febrile transfusion reactions. Vox Sang 1985;49:126-134.

2 Brecher ME, Leger RM, Linden JV, Roseff SD: Technical manual, ed 15. Bethesda, American Association of Blood Banks, 2005

$\checkmark 3$ Decary F, Ferner P, Giavedoni L, Hartman A, Howie R, Kalovsky E, Laschinger C, Malette M, Martyres A, Mervart H, Naylor DH, St. Rose JEM, Shepherd FA, Tibensky D: An investigation of nonhemolytic transfusion reactions. Vox Sang 1984;46: 277-285.

4 Enright H, Davis K, Gernsheimer T, McCullough JJ, Woodson R, Slichter SJ: Factors influencing moderate to severe reactions to PLT transfusions: experience of the TRAP multicenter clinical trial. Transfusion 2003;43:1545-1552.

$\checkmark 5$ Blumberg N, Gettings KF, Turner C, Heal JM, Phipps RP: An association of soluble CD40 ligand (CD154) with adverse reactions to platelet transfusions. Transfusion 2006;46:1813-1821.
6 Kelley DL, Mangini J, Lopez-Plaza I, Triulzi DJ: The utility of $<$ or $=3$-day-old whole-blood platelets in reducing the incidence of febrile nonhemolytic transfusion reactions. Transfusion 2000;40: 439-442.

7 Heddle NM, Klama L, Singer J, Richards C, Fedak P, Walker I, Kelton JG: The role of the plasma from platelet concentrates in transfusion reactions. N Engl J Med 1994;331:625-628.

8 Van Loghem JJ, van der Hart M, Hijmans W, Schuit HR: The incidence and significance of complete and incomplete white cell antibodies with special reference to the use of the Coombs consumption test. Vox Sang 1958;3:203-223.

$\checkmark 9$ Kiefel V, König C, Kroll H, Santoso S: Platelet alloantibodies in transfused patients. Transfusion 2001;41:766-770.

10 Phipps RP, Kaufman J, Blumberg N: Platelet derived CD154 (CD40 ligand) and febrile responses to transfusion. Lancet 2001;357:2023-2024.
11 Kaufman J, Spinelli SL, Schultz E, Blumberg N, Phipps RP: Release of biologically active CD154 during collection and storage of platelet concentrates prepared for transfusion. J Thromb Haemost 2007;5:788-796.

12 Klüter H, Bubel S, Kirchner H, Wilhelm D: Febrile and allergic transfusion reactions after the transfusion of white cell-poor platelet preparations. Transfusion 1999;39:1179-1184.

13 Ezidiegwu CN, Lauenstein KJ, Rosales LG, Kelly KC, Henry JB: Febrile nonhemolytic transfusion reactions. Management by premedication and cost implications in adult patients. Arch Path Lab Med 2004;128:991-995.

14 Wang SE, Lara PN Jr, Lee-Ow A, Reed J, Wang LR, Palmer P, Tuscano JM, Richman CM, Beckett L, Wun T: Acetaminophen and diphenhydramine as premedication for platelet transfusions: a prospective randomized double-blind placebo-controlled trial. Am J Hematol 2002;70:191-194. 
15 Sanders RP, Maddirala SD, Geiger TL, Pounds S, Sandlund JT, Ribeiro RC, Pui $\mathrm{CH}$, Howard SC: Premedication with acetaminophen or diphenhydramine for transfusion with leucoreduced blood products in children. Br J Haematol 2005; 130: 781-787.

16 Geiger TL, Howard SC: Acetaminophen and diphenhydramine premedication for allergic and febrile nonhemolytic transfusion reactions: good prophylaxis or bad practice? Transfus Med Rev 2007;21:1-12.

17 Domen RE, Hoeltge GA: Allergic transfusion reactions: an evaluation of 273 consecutive reactions. Arch Path Lab Med 2003;127:316-320.

18 Sandler SG, Mallory D, Malamut D, Eckrich R: IgA anaphylactic transfusion reactions. Transfus Med Rev 1995;9:1-8.

19 Vassallo RR: Review: IgA anaphylactic transfusion reactions. Part I. Laboratory diagnosis, incidence, and supply of IgA-deficient products. Immunohematology 2004;20:226-233.

20 Sandler SG, Eckrich R, Malamut D, Mallory D: Hemagglutination assays for the diagnosis and prevention of IgA anaphylactic transfusion reactions. Blood 1994; 84:2031-2035.

21 Shimada E, Tadokoro K, Watanabe Y, Ikeda K, Niihara H, Maeda I, Isa K, Moriya S, Ashida T, Mitsunaga S, Nakajima K, Juji T: Anaphylactic transfusion reactions in haptoglobin-deficient patients with $\operatorname{IgE}$ and $\operatorname{IgG}$ haptoglobin antibodies. Transfusion 2002:42:766-773

22 Sandler SG: How I manage patients suspected of having had an IgA anaphylactic transfusion reaction. Transfusion 2006;46:10-13.

23 Ahrens N, Höflich C, Bombard S, Lochs H, Kiesewetter H, Salama A: Immune tolerance induction in patients with $\operatorname{IgA}$ anaphylactoid reactions following longterm intravenous IgG treatment. Clin Exp Immunol 2008;151:455-458.

24 Aster RH: Effect of anticoagulant and ABO incompatibility on recovery of transfused human platelets. Blood 1965;26:732-743.

25 Conway LT, Scott EP: Acute hemolytic transfusion reaction due to ABO incompatible platelet apheresis concentrate. Transfusion 1984;24:413-414.

26 McManigal S, Sims KL: Intravascular hemolysis secondary to ABO incompatible platelet products. An underrecognized transfusion reaction. Am J Clin Pathol 1999;111:202-206.

27 Larsson LG, Welsh VJ, Ladd DJ: Acute intravascular hemolysis secondary to outof-group platelet transfusion. Transfusion 2000;40:902-906.

28 Mair B, Benson K: Evaluation of changes in hemoglobin levels associated with ABO-incompatible plasma in apheresis platelets. Transfusion 1998;38: 51-55.

29 Valbonesi M, De Luigi MC, Lercari G, Florio G, Bruni R, Van Lint MT, Occhini D: Acute intravascular hemolysis in two patients transfused with dry-platelet units obtained from the same ABO incompatible donor. Int J Artif Organs 2000; 23:642-646.

30 Fung MK, Downes KA, Shulman IA: Transfusion of platelets containing ABOincompatible plasma: a survey of 3156 North American laboratories. Arch Path Lab Med 2007;131:909-916.

31 Pietersz RNI, Engelfriet CP, Reesink HW, Davis KG, Lown J, Thomson A, Turek P, Dickmeiss E, Krusius T, Matilainen J, Kretschmer V, Karger R, Reinhardt P, Wiesneth M, Schrezenmeier H, Seifried E, Rebulla P, Greppi N, Riccardi D, Morelati F, Uchikawa M, Tsino NH, Takahashi K, Novotny VMJ, Brand A, Solheim BG, Zupanska B, Lozano M, Mazzara R, Knutson F, Norda R, Knutson F, Norda R, Frey BM, MacLennan S, Heal JM, Blumberg N: Transfusion of apheresis platelets and ABO groups. Vox Sang 2005;88:207-221.

32 Fang CT, Chambers LA, Kennedy J, Strupp A, Fucci MC, Janas JA, Tang Y, Hapip CA, Lawrence TB, Dodd RY: Detection of bacterial contamination in apheresis platelet products: American Red Cross experience, 2004. Transfusion 2005;45: $1845-1852$.

33 te Boekhorst PAW, Beckers EAM, Vos MC, Vermeij H, van Rhenen DJ: Clinical significance of bacteriologic screening in platelet concentrates. Transfusion 2005;45:514-519.

34 Schrezenmeier H, Walther-Wenke G, Müller TH, Weinauer F, Younis A, HollandLetz T, Geis G, Asmus J, Bauerfeind U, Burkhart J, Deitenbeck R, Förstemann E, Gebauer W, Höchsmann B, Karakassopoulos A, Liebscher UM, Sänger W, Schmidt M, Schunter F, Sireis W, Seifried E: Bacterial contamination of platelet concentrates: results of a prospective multicenter study comparing pooled whole blood-derived platelets and apheresis platelets. Transfusion 2007;47:644-652. 